JOURNAL OF

HORTICULTURAL

SCIENCES
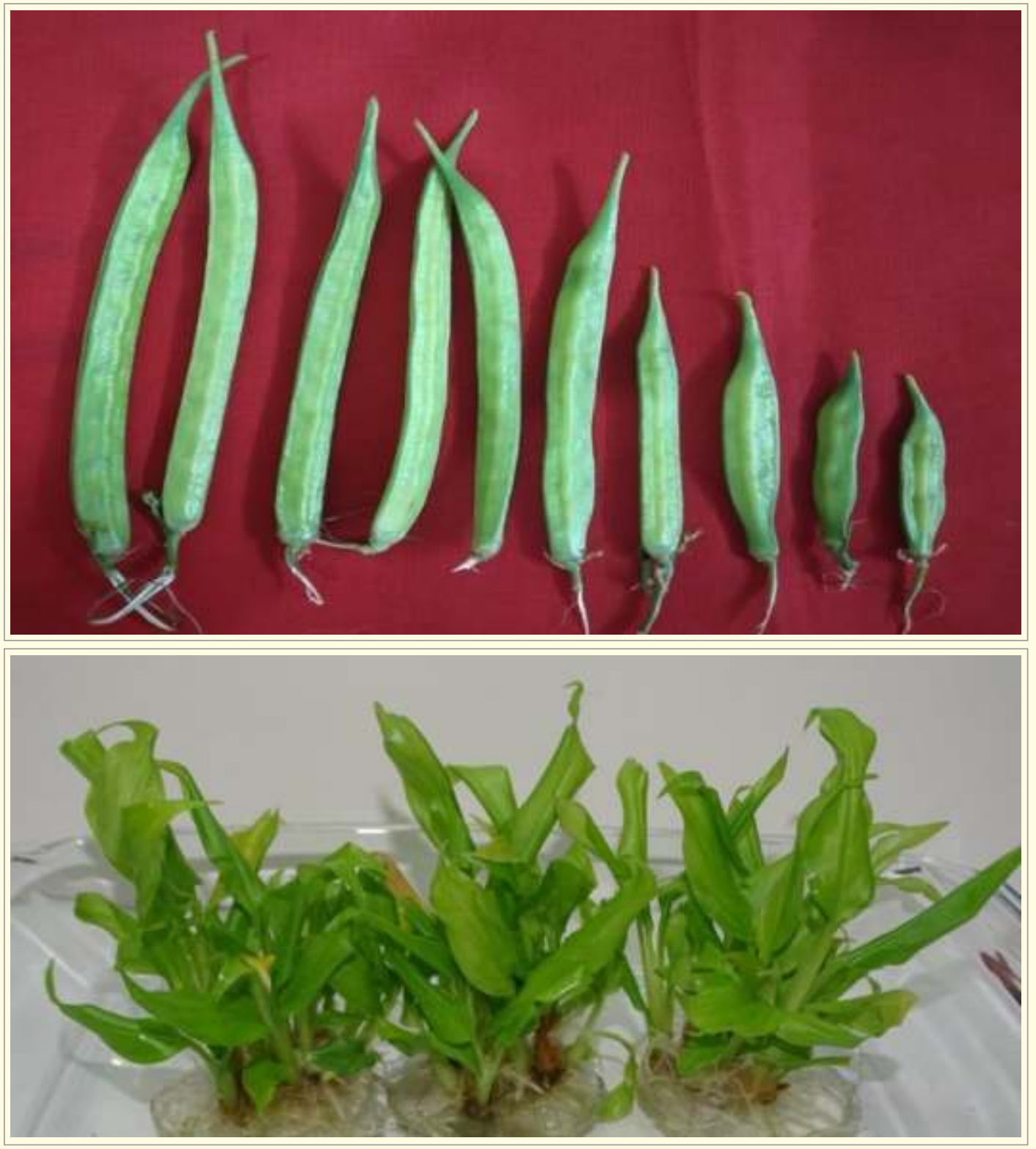

Society for Promotion of Horticulture

ICAR - Indian Institute of Horticultural Research, Bengaluru - 560089 


\section{JOURNAL OF HORTICULTURAL SCIENCES}

\section{ONTENTS}

\section{In this Issue}

\section{Review}

Moringa (Moringa oleifera L.): An underutilized and traditionally valued

tree holding remarkable potential

Jattan M., Kumari N., Raj Kumar, Kumar A., Rani B., Phogat D.S.,

Kumar, S. and Kumar, P.

\section{Original Research in Papers}

Characterization and evaluation of mountain sweet thorn

(Flacourtia montana J. Grah) collections

Tripathi P.C., Ganeshan S., Radhika V. and Shetti D.L.

Optimization of methodology for the extraction of polyphenolic compounds

with antioxidant potential and á-glucosidase inhibitory activity from jamun

(Syzygium cumini L.) seeds

Arivalagan M., Priyanka D.R. and Rekha A.

Genetic variability studies in amaranthus (Amaranthus spp.)

Agadi A.H., Kolakar S., Lakshmana D., Nadukeri S. and Hanumanthappa M.

Morpho-physiological parameters associated with chlorosis resistance to

iron deficiency and their effect on yield and related attributes in potato

(Solanum tuberosum L.)

Challam C., Dutt S., Sharma J., Raveendran M. and Sudhakar D.

Responses of different Okra (Abelmoschus esculentus) cultivars to water

deficit conditions

Ayub Q., Khan S.M., Hussain I., Naveed K., Ali S., Mehmood A., Khan M.J., Haq N.U., Shehzad Q.

Induced variability for yield and its attributing traits in cluster bean

[Cyamopsis tetragonoloba (L. ) Taub] through gamma irradiation

Lavanya H.N., Mishra S., Sood M., Aghora T.S., Anjanappa M., Rao V.K. and Reddy A.B.

In vitro multiplication protocol for Curcuma mangga : Studies on carbon,

Waman A.A., Bohra P., Karthika Devi R. and Pixy J. 
Effect of fungicide and essential oils amended wax coating on quality and shelf life of sweet orange (Citrus sinensis Osbeck)

Bhandari M., Bhandari N. and Dhital M.

Post-harvest quality and quantification of betalains, phenolic compounds and antioxidant activity in fruits of three cultivars of prickly pear

(Opuntia ficus-indica L. Mill)

Gonzalez F.P.H., Saucedo V.C., Guerra R.D., Suarez E.J., Soto H.R.M. Lopez J.A.,

Garcia C.E. and Hernandez R.G.

Soil microbial community dynamics as influenced by integrated nutrient management practices in sweet basil (Ocimum basilicum L.) cultivation Baraa AL-Mansour and D. Kalaivanan

Effect of spectral manipulation and seasonal variations on cut foliage production and quality of Philodendron (Philodendron 'Xanadu')

Sujatha A. Nair, Laxman R.H. and Sangama

\section{Short Communications}

Studies on mutagenic sensitivity of seeds of pummelo (Citrus maxima Merr.)

Sankaran M., Kalaivanan D. and Sunil Gowda D.C.

Isolation and characterization of microsatellite markers from

Garcinia indica and cross species amplification

Ravishankar K.V., Vasudeva R., Hemanth B., Nischita P., Sthapit B.R.,

Parthasarathy V.A. and Rao V.R. 
Original Research Paper

\title{
Genetic variability studies in amaranthus (Amaranthus spp.)
}

\author{
Annapoorna H. Agadi, ${ }^{* 1}$ Kolakar S. ${ }^{1}$, Lakshmana D. ${ }^{1}$, Nadukeri S. ${ }^{2}$ and Hanumanthappa M. ${ }^{3}$ \\ ${ }^{1}$ Department of Crop Improvement and Biotechnology, UAHS, Shivamogga \\ ${ }^{2}$ Department of Plantation Crops, UAHS, Shivamogga \\ ${ }^{3}$ Dean, $\mathrm{COH}$, Mudigere, UAHS, Shivamogga \\ * Corresponding author e-mail : annapurna8021@gmail.com
}

\begin{abstract}
An investigation was carried out to estimate the nature and extent of genetic variability among twenty Amaranthus genotypes (Amaranthus spp.) under randomized block design during the year 2019-20. The phenotypic coefficient of variation was higher than genotypic coefficient of variation for all the traits. High genotypic coefficient of variation (GCV) and phenotypic coefficient variation (PCV) were observed for leaf area, leaf area index, leaf area duration, AGR, dry weight of leaf per plant, specific leaf weight, speed of germination, chlorophyll content and ascorbic acid (vitamin C). Moderate GCV and PCV were observed for leaf length, leaf width, petiole length, dry weight of stem per plant, leaf: stem ratio and foliage yield per plant. The high estimates of heritability coupled with higher values of genetic advance as per cent mean (GAM) were observed for the parameters like test weight, speed of germination, germination percentage, seedling dry matter, seedling vigour index-1, seedling vigour index-2, plant height, leaf length, leaf width, leaf area, leaf area index, leaf area duration, AGR, specific leaf weight, stem weight per plot, dry weight of leaf, dry weight of stem, leaf: stem ratio, foliage yield per plant, chlorophyll, ascorbic acid and beta- carotene content which indicates the predominance of additive gene action. Arka Arunima, Chikmagalur local, IC-551486, IC-551494 and IC-551466 recorded high foliage yield per plot and these can be utilized in further breeding programme.
\end{abstract}

Key words: Genotypic Coefficient of Variation, Genetic Advance as per cent Mean, Heritability and Phenotypic Coefficient Variation

\section{INTRODUCTION}

Amaranthus or chaulai (Amaranthus spp.) is a very popular widespread leafy vegetable throughout the tropics and the temperate zone of the world including India. It is grown throughout the year since it has very quick growth and is suited for crop rotation. Most of the cultivated species are monoecious and windpollinated, while the grain species with colourful inflorescence are occasionally visited by bees (Khoshoo and Pal, 1970). The genus Amaranthus includes 50-60 species, cultivated for leaf as well as for grains and few are wild species. Vegetable type of leaf amaranth i.e., A. tricolor is originated in south East Asia, particularly in India (Rai and Yadav, 2005). Plant hybridization, mutation and polyploidy breeding are the ways and means to restore or create the variability in the existing germplasm. In order to achieve this, collection and characterisation of available genotypes could be the pre-requisite step which provide the necessary information to assess the variability. Studying the phenotypic expression of the plant characters and yield is controlled by the genetic makeup of the plant and environment which is composed of additive variance (heritable) and nonadditive variance including dominance and epistasis (non-allelic) interaction. Therefore, it becomes necessary to partition the observed phenotypic variability into its heritable and non-heritable components with suitable parameters such as genotypic and phenotypic coefficient of variation, heritability and genetic advance. Further, genetic advance can be used to predict the efficiency of selection. With this background, the present investigation was carried out to assess the extent of genetic variability in Amaranthus genotypes for yield and its component traits. 


\section{MATERIALS AND METHODS}

The experiment was laid out in randomized block design (RBD), with two replications during summer, 2019. The genetic factors viz., range, mean, phenotypic coefficient of variation (PCV), genotypic coefficient of variation (GCV), heritability $\left(\mathrm{h}^{2}\right)$, genetic advance (GA) and genetic advance as per cent mean (GAM)were calculated. The details of genotypes used in the study are presented in the Table 1.

Table 1: Details of Amaranthus genotypes used in the study

\begin{tabular}{|c|c|c|}
\hline S. No. & Germplasm & Source \\
\hline 1 & Arka Arunima & IIHR, Bengaluru \\
\hline 2 & IC-551486 & NBPGR, New Delhi \\
\hline 3 & IC-447684 & NBPGR, New Delhi \\
\hline 4 & IC-551482 & NBPGR, New Delhi \\
\hline 5 & IC-551483 & NBPGR, New Delhi \\
\hline 6 & IC-551462 & NBPGR, New Delhi \\
\hline 7 & IC-551492 & NBPGR, New Delhi \\
\hline 8 & IC-551466 & NBPGR, New Delhi \\
\hline 9 & IC-551477 & NBPGR, New Delhi \\
\hline 10 & IC-38174 & NBPGR, New Delhi \\
\hline 11 & IC-551506 & NBPGR, New Delhi \\
\hline 12 & IC-551494 & NBPGR, New Delhi \\
\hline 13 & IC-551459 & NBPGR, New Delhi \\
\hline 14 & IC551468 & NBPGR, New Delhi \\
\hline 15 & Dharwad local & Farmer's field \\
\hline 16 & Kunigal local & Farmer's field \\
\hline 17 & Arbhavi local & Farmer's field \\
\hline 18 & Gokak local & Farmer's field \\
\hline 19 & Mudigere local & Farmer's field \\
\hline 20 & Chikmagalur local & Farmer's field \\
\hline
\end{tabular}

\section{RESULT}

The results of the present experiment carried out with twenty genotypes of amaranthus (Amaranthus tricolor L.) to assess the genetic variability among yield and its component traits are presented under the following headings.

\section{Analysis of variance}

The analysis of variance indicated that significantly higher amount of variability among the genotypes for growth and yield parameters viz., plant height, stem girth, leaf length, number of branches per plant, leaf width, stem girth, petiole length, leaf area, leaf area index, leaf area duration, absolute growth rate (AGR), dry weight of leaf per plant, dry weight of the stem per plant, specific leaf weight, stem weight of plant per plot, leaf :stem ratio, foliage yield per plant, foliage yield per ha, total yield per plant. Similarly, the quality traits viz., ascorbic, beta carotene, total chlorophyll were found to have higher variability Tejaswini et al. (2017). The results are presented in the Table. 2.

Genetic variability, heritability and genetic advance for different parameters of amaranthus genotypes

The results pertaining to genetic factors viz., range, mean, phenotypic coefficient of variation (PCV), genotypic coefficient of variation (GCV), heritability $\left(\mathrm{h}^{2}\right)$, genetic advance (GA) and genetic advance as per cent mean (GAM) are presented in Table 3.

\section{Morphological characteristics}

Plant height and stem girth: The variability for plant height and stem girth was high, as reflected by its wide range from 51.33 (IC-551477) and 11.54 (IC551482 ) to $64.21 \mathrm{~cm}$ (Kunigal local) and $18.93 \mathrm{~mm}$ (Arka Arunima) with mean value of $57.08 \mathrm{~cm}$ and $15.35 \mathrm{~mm}$ respectively. The PCV and GCV values were low (5.79 and $6.15 \%$ respectively). Stem girth exhibited moderate PCV (11.85\%), low GCV $(8.96 \%)$. The magnitude of heritability estimates was high $(88.80 \%)$ and moderate heritability $(57.20 \%)$ with moderate genetic advance over per cent mean $(11.26 \%)$ and $(13.95 \%)$ respectively. 
Table 2: Analysis of variance (mean sum of squares) for growth, yield and biochemical parameters in amaranthus (Amaranthus tricolor L.)

\begin{tabular}{|c|c|c|c|c|c|}
\hline $\begin{array}{l}\text { Source of variation/ } \\
\text { characters }\end{array}$ & Replications & Genotypes & S. $\mathbf{E m} \pm$ & CD $@ 5 \%$ & CV \\
\hline Degree of freedom & 1 & 19 & & & \\
\hline \multicolumn{6}{|c|}{ Growth \& yield parameters } \\
\hline Plant height $(\mathrm{cm})$ & 0.0016 & $20.28 * * *$ & 0.75 & 2.30 & 1.92 \\
\hline Stem girth (mm) & 1.14 & $5.20 * *$ & 0.82 & 2.49 & 7.75 \\
\hline $\begin{array}{l}\text { Number of branches } \\
\text { per plant }\end{array}$ & 0.021 & 2.38 & 0.80 & 2.43 & 9.10 \\
\hline Number of nodes per plant & 0.006 & 2.55 & 0.78 & 2.39 & 8.14 \\
\hline Petiole length (cm) & 0.05 & $1.007^{*}$ & 0.39 & 1.21 & 10.01 \\
\hline Leaf length $(\mathrm{cm})$ & 1.42 & $10.53^{* * *}$ & 0.59 & 1.82 & 8.98 \\
\hline Leaf width $(\mathrm{cm})$ & 0.36 & 1.93 & 0.34 & 1.05 & 9.22 \\
\hline Leaf area $\left(\mathrm{cm}^{2}\right)$ & 0.17 & $7376.70 * * *$ & 1.98 & 6.01 & 2.01 \\
\hline Leaf area index & 0.0007 & $0.01 * * *$ & 0.006 & 0.018 & 4.13 \\
\hline Leaf area duration & 0.68 & $822.32 * * *$ & 1.79 & 5.46 & 3.70 \\
\hline AGR $\quad 0.001$ & $0.005 * * *$ & 0.012 & 0.038 & 11.40 & \\
\hline CGR $\quad 0.09$ & 0.63 & 0.49 & 1.51 & 0.89 & \\
\hline Dry weight of leaf/plant (g) & 10.53 & $30.16 * * *$ & 1.18 & 3.58 & 10.10 \\
\hline Dry weight of stem/plant (g) & 8.77 & $36.25 * * *$ & 1.17 & 3.57 & 7.04 \\
\hline Specific leaf weight & 0.000002 & $0.003 * * *$ & 0.0004 & 0.0012 & 1.41 \\
\hline Stem weight of plant/plot (g) & 0.20 & $8722.80 * * *$ & 0.86 & 2.62 & 0.22 \\
\hline Leaf: stem ratio & 0.00036 & $0.009^{* * *}$ & 0.015 & 0.046 & 4.28 \\
\hline Foliage yield/plant (g) & 8.36 & $489.47 * * *$ & 2.25 & 6.85 & 2.30 \\
\hline Foliage yield/plot $(\mathrm{kg})$ & 0.68 & 0.42 & 0.33 & 1.0148 & 10.61 \\
\hline Foliage yield/ha (t) & 50.62 & 9.23 & 2.52 & 7.6702 & 0.88 \\
\hline \multicolumn{6}{|c|}{ Biochemical parameters } \\
\hline Chlorophyll (mg/g) & 0.046923 & $0.32 * * *$ & 0.08 & 0.26 & 7.00 \\
\hline Ascorbic acid (mg/g) & 0.000023 & $6.38 * * *$ & 0.04 & 0.14 & 1.77 \\
\hline Beta carotene $(\mathrm{mg} / \mathrm{g})$ & 0.001562 & $1.61 * * *$ & 0.02 & 0.06 & 0.38 \\
\hline
\end{tabular}


Genetic variability studies in amaranthus

Table 3: Estimates of mean, range, components of variance, heritability and genetic advance for growth, yield and biochemical parameters in amaranthus (Amaranthus tricolor L.)

\begin{tabular}{|c|c|c|c|c|c|c|c|c|}
\hline $\begin{array}{l}\text { Sl. } \\
\text { No. }\end{array}$ & Character & Range & Mean & GCV\% & PCV\% & $\mathbf{H}^{2}(\%)$ & GA & GAM \\
\hline \multicolumn{9}{|c|}{ Growth \& yield parameters } \\
\hline 1 & Plant height $(\mathrm{cm})$ & $52.3-64.21$ & 57.26 & 5.39 & 5.72 & 88.00 & 5.99 & 10.46 \\
\hline 2 & Stem girth $(\mathrm{mm})$ & $11.54-18.93$ & 15.35 & 8.96 & 11.85 & 57.00 & 2.14 & 13.95 \\
\hline 3 & $\begin{array}{l}\text { Number of branches } \\
\text { per plant }\end{array}$ & $10.75-14.91$ & 13.04 & 5.60 & 10.68 & 27.00 & 0.77 & 6.05 \\
\hline 4 & $\begin{array}{l}\text { Number of nodes } \\
\text { per plant }\end{array}$ & $12.07-15.95$ & 14.06 & 5.60 & 9.88 & 32.00 & 0.91 & 6.53 \\
\hline 6 & Petiole length $(\mathrm{cm})$ & $4.15-7.18$ & 5.78 & 10.02 & 14.17 & 50.00 & 0.84 & 14.60 \\
\hline 7 & Leaf length $(\mathrm{cm})$ & $5.38-14.37$ & 9.68 & 22.83 & 24.53 & 86.00 & 4.23 & 43.76 \\
\hline 8 & Leaf width $(\mathrm{cm})$ & $4.19-7.57$ & 6.21 & 16.83 & 19.19 & 76.00 & 1.65 & 30.39 \\
\hline 9 & Leaf area $\left(\mathrm{cm}^{2}\right)$ & $24.45-268.33$ & 142.62 & 42.56 & 42.60 & 99.00 & 124.89 & 87.57 \\
\hline 10 & Leaf area index & $0.07-0.38$ & 0.21 & 42.06 & 42.26 & 99.00 & 0.18 & 86.22 \\
\hline 11 & Leaf area duration & $38.39-114.16$ & 69.83 & 28.92 & 29.15 & 98.00 & 41.25 & 59.07 \\
\hline 12 & AGR & $0.09-0.26$ & 0.16 & 30.15 & 32.23 & 87.00 & 0.09 & 58.08 \\
\hline 13 & CGR & $1.84-3.66$ & 2.56 & 9.36 & 29.68 & 9.00 & 0.15 & 6.07 \\
\hline 14 & $\begin{array}{l}\text { Dry weight of } \\
\text { leaf/plant }(\mathrm{g})\end{array}$ & $12.39-25.02$ & 16.96 & 21.76 & 23.98 & 82.00 & 6.89 & 40.64 \\
\hline 15 & $\begin{array}{l}\text { Dry weight of } \\
\text { stem/plant }(\mathrm{g})\end{array}$ & $16.01-32.06$ & 24.23 & 16.84 & 18.26 & 85.00 & 7.75 & 32.02 \\
\hline 16 & Specific leaf weight & $0.01-0.19$ & 0.041 & 95.01 & 95.02 & 100.00 & 0.08 & 195.69 \\
\hline 17 & $\begin{array}{l}\text { Stem weight of } \\
\text { plant per plot }(\mathrm{g})\end{array}$ & $600.09-792.78$ & 696.71 & 9.47 & 9.48 & 100.00 & 136.00 & 19.52 \\
\hline 18 & Leaf : stem ratio & $0.41-0.67$ & 0.51 & 13.25 & 13.93 & 90.50 & 0.13 & 25.97 \\
\hline 19 & $\begin{array}{l}\text { Foliage yield/ } \\
\text { plant }(\mathrm{g})\end{array}$ & $113.71-169.40$ & 142.18 & 10.88 & 11.12 . & 95.70 & 31.18 & 21.93 \\
\hline 20 & $\begin{array}{l}\text { Foliage yield/ } \\
\text { plot }(\mathrm{kg})\end{array}$ & $3.89-5.43$ & 4.56 & 6.75 & 12.58 & 28.80 & 0.34 & 7.47 \\
\hline 21 & $\begin{array}{l}\text { Foliage yield/ } \\
\text { ha (t) }\end{array}$ & $19.4500-27.17$ & 23.76 & 6.095 & 14.16 & 18.50 & 1.28 & 5.40 \\
\hline \multicolumn{9}{|c|}{ Biochemical parameters } \\
\hline 22 & Chlorophyll (mg/g) & $1.20-2.70$ & 1.79 & 21.89 & 22.99 & 90.07 & 0.77 & 42.96 \\
\hline 23 & Ascorbic acid $(\mathrm{mg} / \mathrm{g})$ & $1.32-7.00$ & 3.84 & 46.47 & 46.51 & 99.90 & 3.67 & 95.67 \\
\hline 24 & Beta carotene $(\mathrm{mg} / \mathrm{g})$ & $6.92-10.12$ & 8.62 & 10.42 & 10.42 & 99.90 & 1.84 & 21.45 \\
\hline
\end{tabular}


Number of branches per plant and petiole length: The number of branches per plant ranged between 10.50 (IC-551477) and4.15 (IC-551462)to 15.91 (Arka Arunima) and $7.18 \mathrm{~cm}$ (Arka Arunima)with mean value of 13.04 and $5.78 \mathrm{~cm}$ respectively. The moderate estimates of PCV (13.27) and (14.17), low GCV (3.98\%) and moderate (10.02\%) were noticed. Low heritability $(27 \%)$ and low genetic advance as per cent mean (2.46) was observed for the trait.

Petiole length (cm): Petiole length ranged from 4.15 (IC-551462) to $7.18 \mathrm{~cm}$ (Arka Arunima). The average value for the trait was $5.78 \mathrm{~cm}$. PCV $(14.17 \%)$ and GCV $(10.02 \%)$ values were moderate along with moderate heritability $(50 \%)$ and moderate genetic advance as per cent mean (14.60\%).

\section{Leaf characteristics}

Leaf length and width: It ranged from 5.38 (IC5515067 ) to $12.83 \mathrm{~cm}$ (IC-38174) with a mean of $9.68 \mathrm{~cm}$. The high PCV (21.36\%) and moderate GCV $(18.95 \%)$ were observed. High heritability $(78.80 \%)$ coupled with high genetic advance over per cent mean $(34.66 \%)$ was noticed.

Leaf width (cm): The variability observed for Leaf width was high, as reflected by its wide range from 4.59 (IC-551468) to $8.58 \mathrm{~cm}$ (IC-551486) with an average value of $6.21 \mathrm{~cm}$. High estimates of PCV $(20.96 \%)$ and moderate GCV (16.29\%) were observed. The estimates of heritability was high $(60.40 \%)$ along with high genetic advance as per cent mean $(26.08 \%)$.

Leaf area and Leaf area index (LAI): The values for leaf area ranged from 24.45 (IC-551486) to 268.33 $\mathrm{cm}^{2}$ (Arka Arunima) with mean value of $142.62 \mathrm{~cm}^{2}$. High estimates of GCV (42.56\%) and PCV (42.60\%) were found. High heritability (99\%) coupled with high genetic advance as per cent mean $(87.57 \%)$ was observed for the trait.

The values for leaf area index ranged from 0.07 (IC551486) to 0.38 (Arka Arunima) with mean value of 0.21 . High estimates of GCV (42.06\%) and PCV (42.26\%) were found. High heritability (99\%) coupled with high genetic advance as per cent mean $(86.22 \%)$ was observed for the trait.

Leaf area duration (days): The mean value for leaf area duration was 69.83 days with a range of 38.39 (IC-551486) to 114.16 days (Arka Arunima). The estimates of PCV and GCV were high $(29.16 \%$ and $28.92 \%$, respectively). High heritability (98\%) coupled with high genetic advance as per cent mean $(59.07 \%)$ was noticed.

\section{Physiological characteristics}

Absolute growth rate (AGR): The values for AGR ranged from 0.09 (IC-551494) to 0.26 (Arka Arunima) with mean value of 0.16 . the estimates of GCV and PCV observed were high with values 30.15 and 32.23 per cent respectively, high heritability $(87 \%)$ coupled with high genetic advance (58.08) was observed for the trait.

Crop growth rate (CGR): The values for CGR ranged from 1.84 (IC-551483) to 3.67 (Arka Arunima) with mean value of 2.56 . The moderate estimates of GCV (9.36\%) and high PCV (29.68\%) coupled with low heritability $(09.00 \%)$ and low genetic advance as per cent of mean (6.07) was observed.

Specific leaf weight: The values for specific leaf weight ranged from 0.01 (IC-551466) to 0.19 (IC$551486)$ with mean value of 0.04 . The high estimates of GCV (95.01\%) and PCV (95.02\%) was observed. The high estimates of heritability $(100 \%)$ coupled with high genetic advance as per cent of mean (195.69\%) was observed for the trait.

\section{Yield and its component traits}

Foliage yield per plant (g): The mean value for foliage yield per plant was $142.18 \mathrm{~g}$ which range from 114.60 (IC-551468) to $169.40 \mathrm{~g}$ (Arka Arunima). Moderate estimates of GCV (10.88\%) and PCV $(11.12 \%)$ was observed. The high heritability (95.70\%) coupled with high genetic advance as per cent of mean $(21.93 \%)$ was noticed for the trait.

Foliage yield per plot (kg): The estimated value for foliage yield per plot ranged from 3.89 (IC-551468) to $5.43 \mathrm{~kg}$ (Arka Arunima) and mean value for this trait was $4.56 \mathrm{~kg}$. Low GCV (6.75\%) and moderate PCV (12.58\%) values were recorded. The heritability estimated was low $(28.80 \%)$ along with low genetic advance as per cent mean $(7.47 \%)$ was noticed for the trait.

Total yield per plant (g): The mean value for total yield per plant was $175.03 \mathrm{~g}$ which ranged from 150.69 (IC-551468) to 207.59 (Arka Arunima). Low estimates of GCV $(6.12 \%)$ and moderate PCV (11.34\%) was observed. The low heritability (29.10\%) with low genetic advance as per cent of mean (6.80) was noticed for the trait. 
Total yield per plot $(\mathrm{kg})$ : The mean value for total yield per plant was $5.26 \mathrm{~g}$ which ranged from 4.52 (IC-551468) to 6.22 (Arka Arunima). The low estimates of GCV $(6.50 \%)$ and moderate PCV $(11.29 \%)$ was observed. The low heritability $(33.50 \%)$ with low genetic advance as per cent of mean (7.80) was noticed for the trait

\section{Biochemical parameters}

Chlorophyll content (mg/g): Chlorophyll content was ranged from 1.20 (Arbhavi local) to $2.70 \mathrm{mg}$ (Arka Arunima) with a grand mean of $1.79 \mathrm{mg}$. The estimates of GCV and PCV were high $(21.90 \%$ and $22.99 \%$ respectively). High heritability $(90.70 \%)$ was observed along with high genetic advance as per cent mean $(42.96 \%)$ for the trait.

Ascorbic acid (mg/g): Ascorbic acid ranged from 1.32 (IC-447684) to $7.00 \mathrm{mg}$ (Arka Arunima) with a grand mean of $3.84 \mathrm{mg}$. The estimates of GCV and PCV were high $(46.47 \%$ and $46.51 \%$ respectively). High heritability $(99.90 \%)$ was observed along with high genetic advance as per cent mean $(95.68 \%)$ for the trait.

Beta-carotene ( $\mathrm{mg} / \mathrm{g})$ : Beta-carotene content ranged from 6.92 (IC-551483) to $10.12 \mathrm{mg}$ (Mudigere local) with a grand mean of $8.62 \mathrm{mg}$. Moderate estimates of GCV (10.42\%) and PCV (10.42\%) were observed. High heritability $(99.90 \%)$ was observed along with high genetic advance as per cent mean $(21.45 \%)$ for the trait.

\section{DISCUSSION}

For any crop improvement programme, it is important and a pre-requisite to maintain the genetic variability that allows identification of promising genotypes in the germplasm collections that can be used in the breeding programme to develop promising cultivars.

\section{Variability, heritability, genetic advance and genetic advance over mean}

Existence of genetic variability among the genotypes for the characters to be improved is the most basic requirement for successful selection. In the present investigation, variance due to treatments (genotypes) was significant for all the twenty for growth, earliness, yield and leaf quality parameters. It indicated that sufficient variability existed for most of the characters and considerable improvement could be achieved in these characters by selection. However, the analysis of variance by itself is not enough and conclusive to explain all the inherent genotypic variance in the collections. The phenotype of crop is influenced by additive gene effect (heritable), dominance (non-heritable) and epistatic (non-allelic) interaction. Hence, it becomes necessary to split the observed variability into phenotypic variation and genotypic variation which indicates the extent of variability existing for various traits. The estimation of heritability has a greater role to play in determining the effectiveness of selection for a character provided it is considered in conjunction with the predicted genetic advance as suggested by Panse and Sukhatme (1962) and Johnson et al. (1955) as the heritability is influenced by bio-metrical method, generation of hybrid, sample size of experimental material and environment. With these points in view, the results of the variability observed in the twenty amaranthus genotypes evaluated in the present investigation are discussed hereunder.

\section{Phenotypic and genotypic coefficient of variability}

The extent of variability present in the germplasm provides scope for the crop improvement programme and also depends on the extent of heritability for a trait. Variation can be created artificially but the examination of naturally existing variability in the germplasm of the species is also an important task for the breeder.

In the present study, totally twenty genotypes were evaluated to know the extent of variability for growth, yield and quality parameters. The analysis of variance indicated highly significant differences among genotypes for all the characters viz., plant height, stem girth, number of branches per plant, leaf length, leaf area, leaf area index, petiole length, leaf area duration, absolute growth rate, specific leaf weight, foliage yield per plant, total yield per plant, chlorophyll content, ascorbic acid content and beta-carotene content. Thus, it is implied that there was reasonably sufficient variability in the material used for the study, which provides ample scope for selecting superior and desired genotypes by the plant breeders for further crop improvement.

The results from analysis of variance revealed highly significant variation among the genotypes for growth, yield and quality parameters in amaranthus (Table 4) and considerable improvement could be achieved. However, the analysis of variance by 
itself is not enough and conclusive to explain all the inherent genotypic variances in the genotypes. One of the ways, by which variability in the characters could be assessed is through simple approach of examining the range of variations. Range of variation observed for all the traits indicated the presence of sufficient amount of variation among the genotypes for all the characters studied.

Means of genotypes varied greatly for the traits $v i z$. , stem girth, leaf area, leaf area duration, dry weight of leaf per plant, dry weight of stem per plant, foliage yield per plant, foliage yield per hectare indicated the higher magnitude of variability. In the present study, wide range of variability was observed for all the characters.

In the present experiment, high estimates of GCV and PCV values were observed for leaf area, leaf area index, leaf area duration, specific leaf weight. The similar results were also observed by Rani and Veeragavatham (2003) for specific leaf weight; Kusuma et al. (2007) for dry weight of leaf per plant; Anuja and Mohideen (2007), Ramesh et al. (2013) and Panda et al.(2017) for leaf area; Tejaswini et al. (2017) for leaf area index and leaf area duration; Yadav et al. (2014) and Tejaswini et al. (2017) for leaf length.

High GCV and PCV values with narrow difference is an indication of existence of broad genetic base among the population, suggesting stable expression of genotypes for these traits which provides scope for the improvement of these characters through simple selection.

Moderate GCV and PCV were observed for leaf width, petiole length and foliage yield per plant which indicated presence of moderate amount of variability for these traits and little influence of environment on these traits. The similar results are also observed by Ahammed et al. (2012), Hasan et al.(2013), Patial et al.(2014), Buhroy et al. (2017) and Diwan et al. (2017).

It appears that phenotypic variability may be a good measure of genotypic variability for almost all growth characters such as leaf length, leaf width, petiole length and foliage yield per plant as the estimates of GCV and PCV were closer and parallel indicating that they are least affected by environment.

\section{Heritability and genetic advance}

The effectiveness of selection for any character depends not only on the amount of phenotypic and genotypic variability but also on estimates of broad sense heritability.

High heritability was observed for plant height, leaf length, leaf width, leaf area, leaf area index, leaf area duration, AGR, specific leaf weight, foliage yield per plant, chlorophyll, ascorbic acid and betacarotene content which indicates the prevalence of additive gene actions and lesser influence of environment in the expression of these traits, hence these characters are amenable for selection. The similar results were also observed by Pan et al., (2008), Chattopadhyay et al., (2013), Yadav et al., (2014), Venkatesh (2014), Mobina and Jagatpati (2015), Sarker et al., (2016), Buhroy et al., (2017), Lokeshkumar and Murthy (2017), Panda et al., (2017) and Yogendra et al., (2018) for plant height, specific leaf weight, Yogendra et al. (2018) for leaf length. Kusuma et al., (2007) and Ramesh et al., (2013) for dry weight of leaf per plant, dry weight of stem per plant, Tejaswini et al., (2017) for leaf length, leaf width, leaf area, leaf area duration, foliage yield per plant, chlorophyll content, ascorbic acid and beta carotene content.

Heritability in broad sense is not the true indicator of inheritance of traits. Since, only additive component of genetic variance is efficiently transferred from generation to generation. Therefore, heritability in broad sense may mislead in judging the effectiveness of selection for the trait. Considering heritability in broad sense along with genetic advance may reveal the prevalence of specific components (additive or non-additive) of genetic variance and thus, helps in judging the effectiveness of selection for the trait more accurately. High heritability accompanied with high genetic advance indicates the prevalence of additive gene effects and hence, selection would be effective for such traits. From the present investigation characters like leaf length, leaf area, leaf area index, leaf area duration, AGR, specific leaf weight, foliage yield per plant, chlorophyll content, ascorbic acid and beta-carotene content recorded high heritability with high genetic advance over mean. This indicates the predominance of 
additive gene action and amenable for phenotypic selection in early generations, results are in accordance with the findings of Pan et al., (2008), Chattopadhyay et al., (2013), Venkatesh (2014), Yadav et al., (2014), Mobina and Jagatpati (2015) Sarker et al., (2015), Buhroy et al., (2017), Lokeshkumar and Murthy (2017), Panda et al., (2017) and Yogendra et al., (2018) for plant height, specific leaf weight, foliage yield per plot Yogendra et al., (2018) and Kehinde et al., (2013) for leaf length. Kusuma et al., (2007), Ramesh et al., (2013) and Tejaswini et al., (2017) for leaf length, leaf width, leaf area, leaf area duration, foliage yield per plot, chlorophyll content, ascorbic acid and beta carotene content in Amaranthus.

Prevalence of high degree of additive components of genetic variance, high heritability coupled with high genetic advance as per cent mean, presence of high GCV and PCV for the characters viz., leaf length, leaf area, leaf area index, leaf area duration, AGR, specific leaf weight, which indicated lesser influence of environment in expression of these traits and prevalence of additive gene action in their inheritance. Hence, genetic improvements of these traits are amenable for selection.

\section{CONCLUSION}

In the present investigation, high GCV and PCV were observed for parameters like, leaf area, leaf area index, leaf area duration, AGR, dry weight of leaf per plant, specific leaf weight, speed of germination, chlorophyll content and ascorbic acid (vitamin C). It indicated existence of broad genetic base, which would be useful for further selection. The parameters like stem girth, number of branches per plant, leaf length, stem weight per plot, leaf: stem ratio, petiole length and foliage yield per plant are important characters to be accounted for gaining improvement in total yield per plant. Since, these characters had high significant and positive direct effects on foliage yield per plot.

\section{REFERENCE}

Ahammed, A. U., Rahman, M. M. and Mian, M. A. K., 2012. Genetic variability, heritability and correlation in stem amaranthus (Amaranthus tricolor L.). Bangladesh J. Plant Breed. Genet. 25(2): 25-32.

Anuja, S and Mohideen, M. 2007. Variability, heritability and genetic advance studies in amaranthus (Amaranthus spp.). The Asian J. Hortic. 2(1): 63-66.

Buhroy, S., Saraswathi, T and Ramalingam, J. 2017. Genetic basis of yield and quality variations in vegetable amaranth (Amaranthus tricolor) to identify the promising genotypes. Int. J. Curr. Microbiol. App. Sci. 6(4): 2104-2111.

Chattopadhyay, A., Das, S., Rana, N. P., Seth, T and Dutta, S. 2013. Estimation of genetic parameters, inter-relationships and genetic divergence of vegetable amaranth. Int. J. Plant Breed. 7(2): 111-115.

Diwan, I. S., Shukla, N and Kurrey, V. 2017. Genetic studies in amaranthus germplasm. Int. J. Curr. Microbiol. App. Sci. 6(8): 2459-2470.
Hasan, M., Akther, C. A and Raihan, M. S. 2013. Genetic variability, correlation and path analysis in stem Amaranth (Amaranthus tricolor L.) genotypes. The Agric. 11(1): 1-7.

Johnson, H. W., Robinson, H. F. and Comstock, R. E. 1955. Genotypic and phenotypic correlations in soyabean and their implications in selection. Agron. J. 47: 477-483.

Kehinde, V., Dod, V. N., Nagre, P. K., Kale, V. S and Potdukhe, N. R. 2013. Correlation and path analysis in leafy Amaranthus tricolor L. Ann. Pl. Physi. 27(1/2): 27- 29.

Khoshoo, T. N and Pal, M. 1970. Chromosomes Today. 3: 359-267.

Kusuma, V. P., Nagaraja, T. E and Salimath, P. M. 2007. Genetic in grain amaranth. Int. Nat. J. Pl. Sci. 2(2): 145-148.

Lokeshkumar, B. M and Murthy, N. 2017. Genetic variability and divergence studies for yield component traits in grain amaranthus (Amaranthus spp.). Int. J.Curr. Microbiol. App. Sci. 6(12):1276-1285. 
Mobina, P. and Jagatpati, T. 2015. Genetic variability of Amaranthus hybridus in tropical plains of West Bengal. Int. J. Pure App. Biosci. 3(2): 389-395.

Pan, R. S., Singh, A. K., Kumar, S and Rai, M. 2008. Genetic variation and character association in vegetable amaranth (Amaranthus tricolor L.).Veg. Sci. 35(1): 81-83.

Panda, R. K., Mishra, S. P., Nandi, A., Sarkar, S., Pradhan, K., Das, S., Patnaik, A and Padhiary, A. K. 2017. Genetic variability and varietal performance in vegetable amaranthus (Amaranthus spp.). J. Pharmacog. Phytochem. 6(6): $1250-1256$

Panse, V. G and Sukhatme, P. V. 1962. Statistical methods for agricultural workers, $361 \mathrm{pp}$, Indian Council of Agricultural Research, New Delhi.

Patial, M., Chauhan, A., Singh, K.P. and Sharma, D. 2014. Character association and path coefficient analysis in grain amaranth (Amaranthus spp.). Int. J. Agric, Environ. Biotech. 7(1): 101.

Rai, N and Yadav, D. S. 2005. Advances in vegetable production. Researchco Book Centre.

Ramesh, K. S., Mohamed, G. Y. and Govindarasu, R. 2013. Studies on genetic parameters in grain amaranths (A. hypochondriacus) as influenced by plant densities. J. Plant Breed. Genet.1: 34-42.
Rani, A. R. B and Veeraragavathatham, D. 2003. Genetic variability for green yield in amaranthus, South Indian Hortic. 51(1/6): 173-175.

Sarker, U., Islam, M. D. T., Rabbani, M. D. G and Oba, S. 2015. Genotypic variability for nutrient, antioxidant, yield and yield contributing traits in vegetable amaranth. J. Food. Agric. Environ. 12(3\&4): 168-174.

Tejaswini, N., Saidaiah, P., Ravinder, R. K and Ramesh, T. 2017. Evaluation of vegetable amaranth (Amaranthus tricolor L) genotypes for yield and yield attributing traits. J. Pharmacog. Phytochem. 6(6):2572-2578.

Venkatesh, L., Niranjana, M., Nehru, S. D and Manjappa. 2014. Genetic variability, heritability and genetic advance in grain amaranth (Amaranthus spp.). Asian J. Biol. Sci. 9(1): 67-70.

Yadav, R., Rana, J. C and Ranjan, K. 2014. Analysis of variability parameters for morphological and agronomic traits in grain amaranth (Amaranthus spp.) genotypes. The Bioscan. 9(4): 1661-1665.

Yogendra, K., Rameshwar, P. and Puthem, R. S. 2018. Studies on collection and evaluation of genetic variability available in amaranthus (Amaranthus spp.) under Chhattisgarh plain condition. Int. J. Curr. Microbiol. App. Sci. 7(11):3540-3547.

(Received on 5.11.2020, Revised on 06.06.2021, Accepted on 21.06.2021) 